\title{
In vitro Studies on Basella rubra Different Extracts as Inhibitors of Key Enzymes Linked to Diabetes Mellitus
}

\author{
B. Samuel Thavamani ${ }^{1 *}$ and Vanitha Subburaj ${ }^{2}$
}

B. Samuel Thavamani $\mathbf{i}^{*}$ and Vanitha Subburaj ${ }^{2}$

'Department of Pharmacognosy, Sanjo College of Pharmaceutical Studies, Vellapara, Chithali P.O., Kuzhalmannam, Palakkad 678702, Kerala, India. ${ }^{2}$ Department of Pharmacognosy, PSG College of Pharmacy, Peelamedu, Coimbatore, Tamilnadu, INDIA

\section{Correspondence}

Dr. B. Samuel Thavamani,

Professor, Department of Pharmacognosy, Sanjo College of Pharmaceutical Studies, Vellapara, Chithali P.O., Kuzhalmannam, Palakkad 678702, Kerala, India. Phone no: 0422-2570170-5845;

Mobile no: 9865531771

E-mail: samtmani78@rediffmail.com

History

- Submission Date: 28-07-2016

- Review completed: 20-08-2016

- Accepted Date: 02-09-2016

\section{DOI : 10.5530/pj.2017.1.18}

Article Available online

http://www.phcogj.com/v9/i1

\section{Copyright}

(C) 2016 Phcog.Net. This is an openaccess article distributed under the terms of the Creative Commons Attribution 4.0 International license.

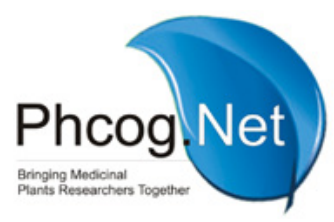

\begin{abstract}
Enzyme, inhibiting carbohydrate metabolism and thereby decreasing glucose level is a class of drugs helpful in the management of type 2 Diabetes mellitus. Naturally existing $\alpha$-amylase and $\alpha$-glucosidase inhibitors from medicinally significant plants are shown to be effective in the management of postprandial hyperglycemia. In this investigation, leaf extract (BRLE), stem extract (BRSE), fruit extract (BRFRE) and flower extract (BRFLE) of Basella rubra were subjected to evaluate their antioxidant potential and their possible inhibitory effects on $\alpha$-amylase and $\alpha$-glucosidase. BRLE, BRSE, BRFRE, BRFLE (at concentration $100 \mu \mathrm{g} / \mathrm{ml}$ ) exhibited $65.78,56.84,63.1,61.03 \%$ of $\alpha$-amylase inhibitory activity respectively with $\mathrm{IC}_{50}$ values of $71.66,89.69$, $73.68,80.37 \mu \mathrm{g} / \mathrm{ml}$ respectively. In the same way BRLE, BRSE, BRFRE, BRFLE (at concentration $100 \mu \mathrm{g} / \mathrm{ml}$ ) exhibited $97.63,92.79,82.17,92.71 \%$ of $\alpha$-glucosidase inhibition with an $I_{50}$ value of $26.97,28.53,41.30$, $38.80 \mu \mathrm{g} / \mathrm{ml}$ respectively. Among the samples, the leaf extract of $B$. rubra registered higher content of total phenolics and flavonoids and also higher antioxidant activity in DPPH, nitric oxide and NBT radical scavenging assays. Though all the parts had shown potent inhibitory effects on $\alpha$-amylase and $\alpha$-glucosidase, the highest inhibitory potency was observed in the leaf extract of Basella rubra $(p<0.001)$.
\end{abstract}

Key words: $\alpha$-Amylase inhibitory activity, Basella rubra, Diabetes mellitus, Postprandial hyperglycemia.

\section{INTRODUCTION}

Diabetic Mellitus (DM) is a disease which is caused due to the metabolic disorder of carbohydrate metabolism. The management of DM was mostly carried out by the treatment of oral hypoglycemic agents or antihyperglycemic agents and insulin. However due to their undesired effect the use of medicinal plants in the management of DM gained considerable interest. Thus the management of DM can be effected by inhibiting pancreatic enzymes like $\alpha$-amylase and $\alpha$-glucosidase which is responsible for the hydrolysis of carbohydrate and thereby causing postprandial hyperglycemia. Basella rubra (BR) belonging to the family Basellaceae is commonly called Malabar spinach and is native to the East Indies. It is a vigorous, climbing tropical vine that may be grown as leafy vegetable for its edible spinach-like stems and leaves or as an ornamental foliage vine. Leaves and stems are a good source of Vitamins A and C, calcium and iron. Basella rubra has been reported to have anti-microbial, ${ }^{1}$ larvicidal, ${ }^{2}$ hypoglycemic, ${ }^{3}$ anti-ulcer, ${ }^{4}$ analgesic, anti-pyretic, diuretic, ${ }^{5}$ and anti-oxidant properties. ${ }^{6}$ Phytochemical investigation of this plant yielded different phytoconstituents like cardiac glycosides, saponins, tannins, flavonoids, terpenoids, carbohydrates, reducing sugars and basellasaponins A, B, C, and D. ${ }^{7}$ The hypoglycemic effect of Basella rubra in streptpzotocin induced diabetic albino rats was reported. ${ }^{8}$

Natural inhibitors of carbohydrate enzymes from plant sources put forth an attractive strategy for the control of postprandial hyperglycemia. This effort has been taken to investigate the $\alpha$-amylase and a-glucosidase inhibitory activity of the leaf, stem, flower and fruit extracts of Basella rubra in the management of diabetes mellitus.

\section{MATERIALS AND METHODS}

\section{Collection of Plant Material}

The plant material was collected from Hudco Colony, Peelamedu, Coimbatore and authentified by Mr. MURTHY G.V.S, Scientist, Botanical Survey of India, Tamilnadu Agriculture University Campus, Coimbatore. A voucher specimen was prepared in the research laboratory and the voucher with no. PSGCP/DPC/03, is maintained for further reference.

\section{Preparation of plant extracts (Leaf, Stem, Fruit and Flower)}

The shade dried parts of the plant were powdered and subjected to defatting with petroleum ether. The marc is then subjected to cold maceration with $70 \%$ Hydroalcohol for $48 \mathrm{hr}$. Finally all the extracts were filtered and concentrated under reduced pressure to get various plant extracts namely Basella rubra Leaf Extract (BRLE), Basella rubra Stem Extract (BRSE), Basella rubra Flower Extract (BRFLE) and Basella rubra Fruit Extract (BRFRE).

\section{Phytochemical Screening}

Different extracts of Basella rubra were subjected to various phyto-chemical tests to find out the presence of sterols, terpenoids, carbohydrates, 
flavonoids, proteins, alkaloids, glycosides, saponins, tannins, volatile oils and mucilage. ${ }^{9}$

\section{Estimation of Total Phenols}

Total phenolic content was determined in all the extracts by FolinCiocalteu method. This test is based on the oxidation of phenolic groups with phosphomolybdic and phosphotungstic acids. After oxidation, a green-blue complex is formed, which is measured at $750 \mathrm{~nm}$. The total phenol content of a tested material can be related to the antioxidant activity shown by it. ${ }^{10}$

\section{Estimation of Total Flavonoids}

Flavonoids present in the extracts were estimated by their characteristic absorption in the UV region and by their specific reaction with aluminium chloride and potassium acetate. ${ }^{11}$

\section{Antioxidant Assay}

Antioxidant potential of different parts of Basella rubra was assessed by DPPH method, ${ }^{12}$ Nitric oxide method ${ }^{13}$ and Nitro blue tetrazolium method. ${ }^{14}$

\section{Alpha Amylase Inhibitory Assay}

In vitro a-Amylase Inhibitory activity of alcoholic extract of various plant parts (leaf, stem, fruit, flower) of BR was carried out by using Kazeem et al 2013 method. ${ }^{15}$ In this assay various concentrations $(20,40,60,80,100 \mu \mathrm{l})$ of different plant parts of alcoholic extract of BR was allowed to react with $250 \mu \mathrm{l}$ of $0.02 \mathrm{~m}$ sodium phosphate buffer ( $\mathrm{pH}$ 6.9) which contains $\alpha$-amylase solution $(0.5 \mathrm{mg} / \mathrm{ml})$ (Hi media $\mathrm{Rm} 638$ - $\alpha$-Amylase from fungi). The content of the tubes was pre incubated at $25^{\circ} \mathrm{C}$ for $10 \mathrm{~min}$ after which $250 \mu \mathrm{l}$ of $1 \%$ starch solution was added in $0.02 \mathrm{M}$ sodium phosphate buffer ( $\mathrm{pH}$ 6.9). The reaction mixture was incubated at $25^{\circ} \mathrm{C}$ for $10 \mathrm{~min}$. The reaction was terminated by adding $500 \mu \mathrm{l}$ of dinitro salicylic acid (DNS) reagent and further incubated in boiling water bath for $5 \mathrm{~min}$ and cooled to room temperature. The content of each test tube was diluted up to $5 \mathrm{ml}$ with distilled water and the absorbance was measured at $540 \mathrm{~nm}$ by Spectrophotometer. The reaction system without plant extracts was used as control and the system without $a$-amylase was used as blank for correcting the background absorbance. The percentage inhibition of a-amylase enzyme was calculated using the following formula.

$$
\% \text { Inhbition }=\frac{\text { Control absorbance }- \text { Corrected test absorbance }}{\text { Control absorbance }} \times 100
$$

\section{Alpha Glucosidase Inhibitory Assay}

In vitro a-Glucosidase Inhibitory activity of hydroalcoholic extract of various plant parts (leaf, stem, fruit, and flower) of BR was carried out by using Kazeem et al 2013 method. In this assay various concentrations $(20,40,60,80,100 \mu \mathrm{l})$ of different plant parts of alcoholic extract of BR was allowed to react with $100 \mu \mathrm{l}$ of $\alpha$-Glucosidase (RM7067 a-Glucosidase from Saccharomyces species) (1 Unit/ml) in $20 \mathrm{mM}$ phosphate buffer ( $\mathrm{pH}$ 6.9). The content of the tubes was pre incubated at $25^{\circ} \mathrm{C}$ for $10 \mathrm{~min} .50 \mu \mathrm{L}$ of p-nitropheynyl glucopyranoside was added to start the reaction. The reaction mixture was incubated at $25^{\circ} \mathrm{C}$ for $20 \mathrm{~min}$. The reaction was terminated by adding $2 \mathrm{ml}$ of $0.1 \mathrm{M}$ sodium carbonate solution and finally made up to $5 \mathrm{ml}$ with distilled water. Then enzyme inhibition was (absorbance) measured at $405 \mathrm{~nm}$ by Spectrophotometer. The reaction system without plant extracts was used as control and the system without $\alpha$-glucosidase was used as blank for correcting the background absorbance. The percentage inhibition of $\alpha$-glucosidase enzyme was calculated using the following formula.

$$
\% \text { Inhbition }=\frac{\text { Control absorbance }- \text { Corrected test absorbance }}{\text { Control absorbance }} \times 100
$$

Where

Corrected test absorbance $=$ Sample absorbance - Blank absorbance The concentration of extract resulting in $50 \%$ inhibition of enzyme activity $\left(\mathrm{IC}_{50}\right)$ was determined graphically using Microsoft excel.

\section{Statistical analysis}

Statistical analysis was performed using GraphPad Prism statistical package (GraphPad Software, USA). The data were analyzed by One-way Analysis of Variance (ANOVA) method followed by Tukey's multiple comparison. The results were considered to be statistically significant when the $P<0.05$. All the results were expressed as mean \pm SD for triplicate determinations.

\section{RESULTS}

\section{Phytochemical study}

Preliminary phytochemical screening of various hydro alcoholic extracts of BRLE, BRSE, BRFRE, BRFLE exhibited the presence of glycosides, terpenoids, carbohydrates, proteins, falvanoids, sterols, tannins, saponins and mucilage (Table 1).

\section{Secondary metabolite}

Estimation of the secondary metabolites showed significant content of total phenolic (25.9 GAE mg/g) and total flavonoid content (4.27 RE mg/g) in BRLE (Table 2).

\section{Antioxidant potential}

Four extracts namely BRLE, BRSE, BRFRE, BRFLE were subjected to in vitro antioxidant activity. Among the four extracts evaluated, hydro alcoholic extract of BRLE showed potent antioxidant property with the minimum $\mathrm{IC}_{50}$ values in the scavenging of DPPH, Nitric acid and NBT assay. All the results were comparable with the standard. The $\mathrm{IC}_{50}$ values of hydro alcoholic extract of BRLE were found to be 10.98, 62.5 and 48.24 against DPPH, Nitric oxide and NBT methods respectively (Table 3).

\section{In vitro a-amylase assay}

The \% inhibition of a-amylase activity of hydro alcoholic extracts of BRLE, BRSE, BRFRE, BRFLE at the concentrations of 20, 40, 60, 80 and $100 \mathrm{mg} / \mathrm{ml}$ as shown in Table 4 was studied in comparison with standard Acarbose. The standard Acarbose showed 70.06 $\pm 3.73 \%$ (at concentration $100 \mu \mathrm{g} / \mathrm{ml}$ ) inhibitory activity of $\alpha$ amylase with IC $_{50}$ value $64.97 \mu \mathrm{g} / \mathrm{ml}$ (Table 6). BRLE (at concentration $100 \mu \mathrm{g} / \mathrm{ml}$ ) exhibited $65.78 \pm 1.51 \%$ of a-amylase inhibitory activity with an $\mathrm{IC}_{50}$ value of $71.66 \mu \mathrm{g} / \mathrm{ml}$. BRSE, BRFRE, BRFLE (at concentration $100 \mu \mathrm{g} / \mathrm{ml}$ ) exhibited $56.84 \pm 2.47$, $63.1 \pm 3.07,61.03 \pm 1.16 \%$ of $\alpha$-amylase inhibitory activity respectively with $\mathrm{IC}_{50}$ values $89.69,73.68,80.37 \mu \mathrm{g} / \mathrm{ml}$ respectively (Table 4 ). Results obtained from the above investigation showed that BRLE showed more potent inhibitory activity of $\alpha$-amylase when compared with BRSE, BRFRE, BRFLE.

The \% inhibition of a-glucosidase activity of hydro alcoholic extracts of BRLE, BRSE, BRFRE, BRFLE at the concentrations of 20, 40, 60, 80 and $100 \mathrm{mg} / \mathrm{ml}$ as shown in Table 4 was studied in comparison with the standard drug i.e. Acarbose. The standard acarbose showed $97.67 \pm 0.89 \%$ (at concentration $100 \mu \mathrm{g} / \mathrm{ml}$ ) inhibitory activity of $\alpha$-glucosidase with IC $_{50}$ value $24.85 \mu \mathrm{g} / \mathrm{ml}$ (Table 6). BRLE (at concentration $100 \mu \mathrm{g} / \mathrm{ml}$ ) exhibited $97.63 \pm 1.16 \%$ of a-glucosidase inhibitory activity with an $\mathrm{IC}_{50}$ value of $26.97 \mu \mathrm{g} / \mathrm{ml}$. Percentage inhibition for BRSE, BRFRE, BRFLE (at concentration $100 \mu \mathrm{g} / \mathrm{ml}$ ) exhibited $92.79 \pm 1.08,82.17 \pm 2.26,92.71 \pm$ $2.92 \%$ of $\alpha$-glucosidase inhibition with an $\mathrm{IC}_{50}$ value as in Table 4 (28.53, 
Table 1: Phytochemical analysis for Hydroalcoholic extract of various plant parts of Basella rubra

\begin{tabular}{ccccc}
\hline Name of the test & $\begin{array}{c}\text { Leaf } \\
\text { Extract }\end{array}$ & $\begin{array}{c}\text { Stem } \\
\text { Extract }\end{array}$ & $\begin{array}{c}\text { Flower } \\
\text { Extract }\end{array}$ & $\begin{array}{c}\text { Fruit } \\
\text { Extract }\end{array}$ \\
\hline Alkaloids & - & - & - & - \\
Glycosides & + & + & - & - \\
Terpenoids & + & + & + & + \\
Carbohydrates & + & + & + & + \\
Proteins & + & + & + & + \\
Flavonoids & + & + & + & + \\
Sterols & + & + & + & + \\
Tannins & + & + & + & + \\
Anthraquinone & - & - & - & - \\
Saponins & + & + & - & - \\
Mucilage & + & + & - & - \\
\hline
\end{tabular}

$(+)$ indicates positive reaction (-) indicates negative reaction

Table 2: Estimation of Phenolic and Flavonoid Content of different parts of Basella rubra

\begin{tabular}{ccc}
\hline Name of the part & $\begin{array}{c}\text { Total Phenolics } \\
\text { GAE } \mathbf{~ m g} / \mathbf{g}\end{array}$ & $\begin{array}{c}\text { Total Flavonoids } \\
\text { RE } \mathbf{~ m g / g}\end{array}$ \\
\hline BRLE & 25.9 & 4.27 \\
BRSE & 23.8 & 3.89 \\
BRFRE & 18.5 & 2.97 \\
BRFLE & 20.5 & 3.34 \\
\hline
\end{tabular}

Data are mean $\pm \mathrm{SD}$ or $\% \pm \mathrm{SD}$ for triplicate measurements.

GAE - gallic acid equivalent, RE - Rutin equivalent.

Table 3: In vitro antioxidant studies of different extracts of Basella rubra by DPPH, Nitric acid and NBT and methods.

\begin{tabular}{cccc}
\hline Different extracts / & \multicolumn{3}{c}{ IC50 values $(\mathrm{mg} / \mathrm{ml})$} \\
\cline { 2 - 4 } Standard & DPPH & Nitric oxide & NBT \\
\hline BRLE & $10.98 \pm 0.72$ & $62.5 \pm 0.42$ & $48.24 \pm 0.32$ \\
BRSE & $14.78 \pm 0.54$ & $125.4 \pm 0.82$ & $104.36 \pm 0.49$ \\
BRFRE & $11.74 \pm 0.36$ & $75.2 \pm 0.36$ & $94.38 \pm 0.54$ \\
BRFLE & $16.72 \pm 0.62$ & $82.4 \pm 0.52$ & $71.59 \pm 0.69$ \\
\hline
\end{tabular}

Data are mean \pm SD or $\% \pm$ SD for triplicate measurements.

Table 4: Alpha Amylase Inhibitory Assay of various extracts of Basella rubra

\begin{tabular}{cccccc}
\hline \multirow{2}{*}{ Conc $\mathrm{mcg} / \mathrm{ml}$ l } & \multicolumn{5}{c}{ \% Inhibition } \\
\cline { 2 - 6 } & Acarbose & BRLE & BRSE & BRFRE & BRFLE \\
\hline 20 & $22.50 \pm 0.90$ & $20.46 \pm 0.98$ & $16.79 \pm 0.57$ & $17.21 \pm 0.65$ & $12.99 \pm 0.36$ \\
40 & $36.25 \pm 0.69$ & $30.33 \pm 0.85$ & $25.33 \pm 0.30$ & $30.48 \pm 0.96$ & $21.61 \pm 0.98$ \\
60 & $46.63 \pm 0.79$ & $40.62 \pm 0.99$ & $32.03 \pm 0.55$ & $35.34 \pm 1.14$ & $38.56 \pm 1.32$ \\
80 & $62.47 \pm 0.69$ & $51.88 \pm 0.80$ & $43.85 \pm 0.72$ & $52.59 \pm 1.19$ & $50.54 \pm 0.69$ \\
100 & $70.83 \pm 1.48$ & $65.53 \pm 1.18$ & $56.39 \pm 0.90$ & $63.05 \pm 0.55$ & $61.35 \pm 1.10$ \\
\hline
\end{tabular}

Data are mean \pm SD or $\% \pm$ SD for triplicate measurements. 
Samuel and Vanitha : In-vitro anti-diabetic studies of Basella rubra

Table 5: Alpha Glucosidase Inhibitory Assay of various extracts of Basella rubra and Acarbose

\begin{tabular}{cccccc}
\hline \multirow{2}{*}{ Conc $\mathrm{mcg} / \mathrm{ml}$} & \multicolumn{5}{c}{ \% Inhibition } \\
\cline { 2 - 6 } & Acarbose & BRLE & BRSE & BRFRE & BRFLE \\
\hline 20 & $50.57 \pm 0.94$ & $44.42 \pm 1.25$ & $42.91 \pm 2.61$ & $41.01 \pm 1.85$ & $40.39 \pm 1.73$ \\
40 & $60.7 \pm 0.86$ & $66.91 \pm 1.66$ & $65.03 \pm 1.77$ & $50.91 \pm 1.01$ & $55.01 \pm 1.91$ \\
60 & $77.13 \pm 1.71$ & $73.38 \pm 2.64$ & $71.84 \pm 1.83$ & $62.8 \pm 2.93$ & $63.83 \pm 0.33$ \\
80 & $92.31 \pm 2.66$ & $90.47 \pm 0.96$ & $85.81 \pm 2.49$ & $71.62 \pm 1.46$ & $81.92 \pm 1.26$ \\
100 & $97.67 \pm 0.89$ & $97.63 \pm 1.16$ & $92.79 \pm 1.08$ & $82.17 \pm 2.26$ & $92.71 \pm 2.92$ \\
\hline
\end{tabular}

Data are mean $\pm \mathrm{SD}$ or $\% \pm \mathrm{SD}$ for triplicate measurements.

Table 6: IC50 Values of various extract of Basella rubra and Acarbose

\begin{tabular}{ccc}
\hline Name & $\begin{array}{c}\text { IC }_{50} \text { Values } \\
\text { of } \boldsymbol{a} \text {-amylase }\end{array}$ & $\begin{array}{c}\text { IC }_{50} \text { Values } \\
\text { of a-glucosidase }\end{array}$ \\
\hline Acarbose & 64.97 & $24.85 \mu \mathrm{g} / \mathrm{ml}$ \\
BRLE & 71.66 & $26.97 \mu \mathrm{g} / \mathrm{ml}$ \\
BRSE & 89.69 & $28.53 \mu \mathrm{g} / \mathrm{ml}$ \\
BRFRE & 73.68 & $41.30 \mu \mathrm{g} / \mathrm{ml}$ \\
BRFLE & 80.37 & $38.80 \mu \mathrm{g} / \mathrm{ml}$ \\
\hline
\end{tabular}

Data are mean \pm SD or $\% \pm$ SD for triplicate measurements.

$41.30,38.80 \mu \mathrm{g} / \mathrm{ml}$ ) respectively. Results obtained from the above investigation showed that BRLE showed more potent inhibitory activity of a-glucosidase when compared with BRSE, BRFRE, BRFLE.

\section{DISCUSSION}

Diabetes mellitus is a common metabolic disorder that increases the postprandial glucose level which may lead to multiple organ damage and increase the risk of cardiovascular diseases which are the most common causes of death among people with diabetes. Management of blood glucose level is critical in the early treatment of diabetes mellitus and its complication. Sharp rise in the blood glucose level after food intake is aided by $\alpha$-Amylase and $\alpha$ - Glucosidase enzymes, which break the carbohydrate to simple absorbable sugars. ${ }^{16}$ Synthetic enzyme inhibitors such as acarbose, voglibose, miglitol, are useful as oral hypoglycemic drugs for the control of post prandial hyperglycemia especially in type II diabetes patients. ${ }^{17}$ These inhibitors delay carbohydrate digestion and prolong the time taken for glucose absorption in intestine. ${ }^{18}$ Chronic usage of these inhibitors in conjunction with other antidiabetic drugs leads to GI side effects like abdominal discomfort, flatulence and diarrhea. ${ }^{19}$ Several plants have been identified as potential source of drugs in Indian system of medicine for the treatment of diabetes.

Phenolic compounds, whose formation is associated with the normal metabolism of aerobic cells can protect the human body from free radicals. Such compounds are strong in antioxidants and can remove free radicals, chelate metal catalysts, activate antioxidant enzymes, reduce a-tocophenol radicals and inhibit oxidases..$^{20}$ Derivatives of flavonoids have been found in many fruits and vegetables. Further, numerous studies have shown that majority of the antioxidant activities maybe from compounds such as flavonoids, isoflavones, flavones, anthocyanins, catechin and isocatechin rather than from vitamins $\mathrm{C}, \mathrm{E}$ and $\beta$-carotene. ${ }^{21}$ Flavonoids have antioxidant activity and could therefore lower cellular oxidative stress. $^{22}$

In the present study, BRLE showed a significant $(\mathrm{p}<0.001)$ inhibition of $\alpha$-amylase and $\alpha$-glucosidase activity at all concentrations tested and hence it can be used for the management of diabetes mellitus.

\section{CONCLUSION}

It is concluded by the study that the percentage inhibition of leaf extract of Basella rubra is more than that of the extracts of stem, flower and fruit. The $\mathrm{IC}_{50}$ value of leaf extract is less than that of stem, fruit and flower extracts of Basella rubra and hence it shows high alpha amylase and high alpha glucosidase inhibitory action. This activity may be due to the significant antioxidant property which may be due to high levels of phenolic and flavonoid content. However, further study is needed to isolate the active principle(s) in this plant which is responsible for this activity.

\section{ACKNOWLEDGEMENT}

The authors thank the management of Sanjo College of Pharmaceutical Studies for the opportunity given and PSG College of Pharmacy for doing this research work.

\section{CONFLICT OF INTEREST}

The authors have no conflict of interest

\section{REFERENCES}

1. Sen K, Goel A, Rawal S, Mahajan N, Baboo S, et al. Antimicrobial Activity of Basella rubra leaves. Int J Pharmaceutical Sci and Res. 2010;1(2):88-91.

2. Krishnappa K, Elumalai K. Mosquitocidal properties of Basella rubra and Cleome viscosa against Aedes aegypti (Linn.) (Diptera:Culicidae). Eur Rev Med Pharmacol Sci. 2013;17(9):1273-7. PMid:23690200.

3. Nirmala A, Saroja S, Gayathri Devi S. Phytochemical screening and antihyperglycemic activity of Basella rubra recent research. Sci Technol. 2011;3(11):80-3.

4. Deshpande S, Shah GB, Deshpande I, Parmar NS. Antiulcer Activity of Aqueous Extract of Basella rubra in Albino Rats. J Nat Remedies. 2003;3(2):212-4.

5. Hukkeri VI, Patil BS, Savadi RV Nagathan CV. Analgesic, antipyretic and diuretic activities of Basella rubra Linn. Indian Drugs. 2004;41(9):536-9.

6. Nagarajan A, Rajkumar G, Sellamuthu M, Venkararamegowda S, Anita M. Evaluation of Basella rubra I., Rumex nepalensis spreng. and Commelina benghalensis L. for antioxidant activity. Int J Pharm Pharma Sci. 2012;4(3):714-20.

7. Murakami T, Hirano K, Yoshikawa M. Medicinal foodstuffs. XXIII. Structures of new oleanane-type triterpene oligoglycosides, basellasaponins $A, B, C$ and $D$, from the fresh aerial parts of Basella rubra L. Chem. Pharm Bulletin. 2001;49(6):776 http://dx.doi.org/10.1248/cpb.49.776

8. Nirmala A, Saroja S, Vasanthi HR, Lalitha G. Hypoglycemic effect of Basella rubra in streptozotocin-induced diabetic albino rats. J Pharmacognosy Phytotherapy. 2009;1(2):25-30.

9. Kokate CK, Purohit AP, Gokhale JB. Pharmacognosy, Nirali prakasham, pune $36^{\text {th }}$ edition. 2006; 106-9, 271-2, 593-7.

10. Kumaran A, Karunakaran RJ. Activity-guided isolation and identification of free radical-scavenging components from an aqueous extract of Coleus aromaticus. Food Chem. 2007;100(1):356-361. http://dx.doi.org/10.1016/j.foodchem.2005.09.051.

11. Rohman A, Riyanto S, Yuniarti N, Saputra WR, Utami R, et al. Antioxidant activity, total phenolic and total flavanoid of extracts and fractions of red fruit (Pandanus conoideus Lam). Int Food Res. 2010;17(1):97-106.

12. Gamez EJ, Lujengi L, Lee SK, Zhu LF, Zhou BN, et al. Antioxidant flavonoid glycosides from Daphniphyllum calycinum. J Nat Prod. 1998;61(5):706-8. http:// dx.doi.org/10.1021/np9800203; PMid:9599286.

13. Gudda DS, Jayaprakash K, Lingamallu JR. Antioxidant activities of flavidin in 
different in vitro model system. Bio Org Med Chem. 2004;12(19):5141-6. http:// dx.doi.org/10.1016/j.bmc.2004.07.028; PMid:15351397.

14. Kunchandy E, Rao MNA. Oxygen radical scavenging activity of curcumin. Int J Pharmaceutics. 1990;58(3):237-40. http://dx.doi.org/10.1016/0378-5173(90)90201-E.

15. Kazeem MI, Dansu TV, Adeola SA. Inhibitory effect of Azadirachta indica A. juss leaf extract on the activities of alpha-amylase and alpha-glucosidase. Pak J Biol Sci. 2013;16(21):1358-62. http://dx.doi.org/10.3923/pjbs.2013.1358.1362.

16. Kwon YI, Vattem DA, Shetty K. Evaluation of clonal herbs of Lamiaceae species for management of diabetes and hypertension. Asia Pac J Clin Nutr. 2007; 15(1):107-18

17. Gin H, Rigalleau V. Post-prandial hyperglycemia and Diabetes. Diab. Metabol. 2000;26:265-72. PMid:11011218

18. Bhandari MR, Jong AN, Hong G, Hawabata J. Alpha glucosidase and alpha amylase inhibitory activities of a Nepalese medicinal herb Pakhanbhed (Bergenia ciliate Haw). Food Chem. 2008;106(1):247-52. http://dx.doi.org/10.1016/j.foodchem.2007.05.077.

19. Shai L J, Masoko P, Mokgotho MP, Magano SR, Mogale AM, et al. Yeast alphaglucosidase inhibitory and antioxidant activities of six medicinal plants collected in Phalaborwa, South Africa. S Afr J Bot. 2010;76(3):465-70. http://dx.doi. org/10.1016/j.sajb.2010.03.002.

20. Oboh G, Puntel RL, Rocha JBT. Hot pepper (Capsicum annuum, Tepin \& Capsicum chinese, Habanero) prevents $\mathrm{Fe} 2^{+}$- induced lipid peroxidation in brain- In vitro. Food Chem. 2007;102(1):178-85. http://dx.doi.org/10.1016/j.foodchem.2006.05.048

21. Rong T. Chemistry and biochemistry of dietary polyphenol; A Review Nut. 2010;2:1231-1246.

22. Oboh G, Rocha JBT. Antioxidant in foods: A new challenge for food processors: Leading edge antioxidants research. New York: Nova Science Publishers Inc. 2011;35-64.

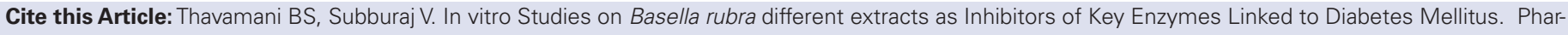
macogn J. 2017; 9(1):107-11. 